\title{
Dynamic linkages between Non-renewable energy, Renewable energy and Economic growth through nonlinear ARDL approach: Evidence from Malaysia
}

Rafia Afroz ( $\nabla$ rafia@iium.edu.my)

International Islamic University Malaysia https://orcid.org/0000-0002-8276-8325

Md Muhibbullah

International Islamic University Malaysia

\section{Research Article}

Keywords: Economic growth, Malaysia, Renewable energy, NARDL, Asymmetric, Nonrenewable energy

Posted Date: September 28th, 2021

DOl: https://doi.org/10.21203/rs.3.rs-941618/v1

License: (c) (1) This work is licensed under a Creative Commons Attribution 4.0 International License.

Read Full License

Version of Record: A version of this preprint was published at Environmental Science and Pollution Research on February 24th, 2022. See the published version at https://doi.org/10.1007/s11356-02219346-0. 


\title{
Dynamic linkages between Non-renewable energy, Renewable energy and Economic growth through nonlinear ARDL approach: Evidence from Malaysia
}

\author{
Rafia Afroz* \\ Department of Economics, Faculty of Economics and Management Science \\ International Islamic University Malaysia. \\ Email: rafia@iium.edu.my \\ Md Muhibbullah \\ Department of Economics, Faculty of Economics and Management Science \\ International Islamic University Malaysia. \\ Email: muhibedu@gmail.com \\ *Corresponding Author
}

\begin{abstract}
The purpose of this paper is to investigate the links between renewable energy (RE), nonrenewable energy (NRE), capital, labour and economic growth, using the Non-linear Auto Regressive Distributive Lag (NARDL) model in Malaysia for the period of 1980-2018. The results of NARDL confirm the asymmetric effect of RE and NRE consumption on the economic growth in the long run as well as short run in Malaysia. The findings also show that in the long and short-run, positive shocks of NRE are greater than the positive shocks of RE. It indicates that Malaysia's economic growth is highly dependent on NRE which is not a good indication as NRE consumption increases carbon dioxide $\left(\mathrm{CO}_{2}\right)$ emission in the country. Moreover, the empirical results of this study demonstrated that RE consumption reduction accelerates economic growth whereas NRE consumption reduction decreases economic growth. It can have claimed that in Malaysia RE is still more expensive than NRE. In conclusion, this study offered a variety of measures to develop RE to reduce the dependency on NRE consumption.
\end{abstract}

Keywords: Economic growth, Malaysia, Renewable energy, NARDL, Asymmetric, Nonrenewable energy

Acknowledgement: The authors would like to acknowledge the P-RIGS funding of "Digital development, Economics Growth. Environmental Sustainability and Population Health in Malaysia: Applying Response Surfaces for the F-test of cointegration model" (Ref no: PRIGS18-006-006)

\subsection{Introduction}

Malaysia is a developing economy with a gross domestic product(GDP) per capita of 11414.8 (current US\$), based on a 4.3 per cent steady rate of GDP growth in 2019 (World Bank, 2020). It is projected that Malaysia's energy demand would increase by 4.8 per cent by 2030. (WEMO, 2017). Non-renewable energy(NRE) originates from sources which will be exhausted or not refilled in our lives - or perhaps in many, many lives. Fossil fuels: coal, petroleum and natural gas are the main sources of non-renewable energy. Malaysia depends largely on fossil fuels, with $53 \%$ of its coal, $42 \%$ of the natural gas and $5 \%$ of hydropower (along with other RE sources) (WEMO, 2017). The country's ultimate energy consumption would triple by 2030 
notwithstanding current demand levels (WEMO, 2017). Malaysians have a total resource of 4.73 billion barrels of crude oil in 2017, but we must be aware that one day this reserve may be depleted if another source of this NRE is not found (Štreimikiene and Baležentis, 2015; Ashnani et al., 2014). Although Malaysia is $16^{\text {th }}$ in terms of its natural-gas reserves (Central Intelligence Agency, 2011), present natural gas production is reported to be maintained only for around 29 years (Ahmad et al., 2011). Malaysia promised to cut carbon discharges of 40 percent by 2025 from the base year 2005 at the Copenhagen Conference of the Parties (COP15, 2009). Renewable energy (RE) is an alternative to traditional fossil-based energy and is less environmentally damaging. In Malaysia their usage for power generation is limited, despite the continuing attempts to encourage the use of RE sources. In 2014, just 1\% of total power produced was sourced by RE sources (Energy Commission, 2017). The results of the $10^{\text {th }}$ Malaysian Plan (2011-2015) demonstrate that Malaysia achieved just $300 \mathrm{MW}$ in 2015 with the expiry of Malaysia's tenth plan, despite its target of $985 \mathrm{MW}$ for the RE (Energy Commission, 2017). The government has offered electricity providers several types of green financial incentives as well as feed-in tariffs (FiT) and new energy metering (NEM) in order to help execute the laws. Malaysia still uses fossil fuels to generate energy following the adoption of all these restrictions. From 1978 to 2015, the energy balance in Malaysia was mostly dependent on fossil fuels, as seen in Figure 1.

In 2015, RE represented about 5.2 percent of Malaysia's current total consumption while RE output looks to be restricted to 4 percent (Figure 2(A)). The decline in RE consumption is seen by Figure 2(B). It is also noted that Malaysia increased its $\mathrm{CO}_{2}$ emissions from 113,853.4 kilogrammes to 257,840 kilogrammes each year between 1999 and 2018 by 4.62 percent (Figure 2(C)). Energy is a critical input and a key necessity in social and economic growth together with other production variables (such labour and capital) (Ghali and El-Sakka 2004). Most economic and social activities require energy. Energy consumption has demonstrated an intimately connection with economic growth (Saudi et al., 2019). In the growing process of Malaysia, energy became one of the main aspects in particular its contribution to the industrial and services efficiency of this nation (Javid \& Sharif, 2016; Nugraha \& Osman, 2019).

As seen in Figure 3, the average annual growth rate for final energy consumption is higher than the average annual increase for primary energy production. Malaysia has an abundance of RE including forests, leftovers of palm oil, residues of mills, solar, hydropower, municipal garbage, land and rice (Poh and Kong, 2002). Malaysia will have to spend substantial quantities of RE to minimize greenhouse gas emissions in order to fulfil this rising demand for energy and avoid energy-related environmental losses from fossil fuels. To consider the main cornerstone for sustainable energy future, it is important to highlight the relation among NRE, $\mathrm{RE}$ and economic growth in Malaysia. The remainder of the study is: the following section reviews literature and indicates the literature gap to be addressed in this study. The specification of the model, data and estimation procedure are then approached in the methodology section in part three, the empirical results and discussion followed in part four and the conclusion in part five included the recommendation with brief discussion of important findings of this study.

\subsection{Literature Review}

Previous literature found that a country's energy usage has different effects, such as negative, positive and neutral on its economic growth. This link differs mostly because of the time frame, location, duration and methodological difference applied. The main basis for these connections is four assumptions. When the relationships between energy consumption and economic growth are unique, it is called a hypothesis of growth. When the direction of causality switches 
from economic growth to energy consumption, the hypothesis of causality is conservative. While both variables influence one another, they are called a bidirectional causality and are specified as a hypothesis for feedback. If the variables do not have a connection, it means neutral hypothesis.

It is noticed that most research has adopted the neoclassical production model in which labour and capital are the major components to economic growth. Thus, some research incorporated RE and NRE to analyse their impact on economic growth in addition to capital and labour (Chen et al., 2020; Baz et al., 2019; Q. Ali, et al., 2019). Few studies have concluded that the relationship between RE use and economic growth is not substantial (Isik et al., 2018; InglesiLotz \& Dogan, 2018; Maji et al., 2019). In contrast, Chen et al.,2020 observed strong positive relationships with those variables in developing nations if they cross a certain RE consumption level or threshold level. Luqman, M et al., 2019 also examines the asymmetric effects of RE and nuclear energy on economic growth by expanding production function in Pakistan, together with labour and capital. Their study utilized annual data from 1990-2016 to obtain reliable evidences using NARDL model. The results indicate that the variables are asymmetrically cointegrated. The results show that renewable energy affects economic growth positively. In addition, the production of capital adds to economic growth positively. In addition, several research show that RE use has a negative effect on economic growth. In comparison to NRE, $\mathrm{RE}$ is expensive. Therefore, countries with large populations and extensive energy expansion benefit from NRE sources for economic reasons. The influence of RE on economic growth and $\mathrm{CO}_{2}$ emissions in developing countries was analysed by a recent study (Shah et al., 2020). Their results confirm that RE has significant positive impact on economic growth. Shastri, S et al., 2020 examines the connection between economic growth, RE and NRE consumption in India between 1971 and 2017. The NARDL model and asymmetric causal test are used in this study for the exploration of nonlinearities in the dynamic interaction. The results show that the influence on economic growth of RE and NRE use is both long-term and short-term asymmetrical. A positive shock in the long run is having a favourable impact on growth for the consumption of NRE and RE. But the negative shocks in the consumption of non-renewable energy have greater negative consequences on economic growth. The nonlinear causality test results show that NRE and RE consumption have a unidirectional causality to economic growth.

On the other hand, few studies have been carried out earlier in Malaysia concerning the consumption of energy and economic growth, including Begum et al. (2015), Tang and Tan (2014), Li, and Solaymani (2021); Nurgazina, Z et al., 2021. For instance, Begum et al., 2015 show that energy consumption per capita as well as per capita GDP have a long-term positive impact, but the population growth rate does not have a significant impact on the emission of per capita $\mathrm{CO}_{2}$. Tang and Tan, 2014 reported that energy consumption and GDP Granger causes to each other in the short and long run. Very recently, Li and Solaymani, 2021 have indicated that overall long-term economic expansion contributes more widely to the growth of energy consumption than in the short term. Nurgazina, $Z$ et al., 2021 demonstrate that $1 \%$ expansion in energy usage, trade openness and urbanization will worsen the environment by $0.18 \%, 0.03 \%$ and $2.51 \%$, respectively. Most of them, however, considered the collective links between energy consumption, $\mathrm{CO}_{2}$ emissions and economic growth. Hence, research on the individual impact of RE and NRE on economic growth is, however, crucial, as the outcomes of this kind of research will allow policymakers to determine what energy consumption should be encouraged to accelerate economic growth. The RE and NRE's comparative contribution in economic growth is still silent in Malaysia. Therefore, this research covers this vacuity and 
covers RE and NRE to stress its importance and presents an economic assessment for the energy market in Malaysia. This research contributes in numerous ways to the energy literature.

First, from the above-mentioned literature study, it is found that RE in developing nations has a negative or neutral influence on economic growth. However, in Malaysia, no research has been undertaken to investigate the RE's comparative role on economic growth. In this context, this study analyses the individual impact of RE and NRE on economic growth, whereas most previous studies examined the association between total energy consumption, economic growth and $\mathrm{CO}_{2}$ emission. This disintegration allows us to assess the comparative power of both types of energy consumption in the growth process; Secondly, this is the first such analysis in Malaysia with the newest data, which offers a clear insight into the policy makers of this region. Third, in addition to capital and labour, two extra variables, such as RE and NRE are included in the neo-classical production function in a multivariate frame to address the potentially neglected variable biases. Fourthly, because of the non-availability of data in many nations, most of which are not normally distributed. Hence, the NARDL approach is suitable for non-linear asymmetric analysis. Therefore, this study contributes to current literature through NARDL approach (Shin et al. 2014) to analyze the asymmetrical link between RE, NRE and economic growth in Malaysia as a single country.

\subsection{Methodology}

\subsection{Specification of the Model}

The most popular Neoclassical growth model (Solow, 1956) uses economic growth to recognize mostly the development of the contemporary world. In the neoclassical economic model, goods are produced by capital and labour input as a closed economic system. However, energy together with capital and labour are regarded a critical input in the growing infrastructure process (Baz et al., 2021). Cobb-Douglas is a frequently used production function, known as an easy tool to link production to economic considerations, written as:

$$
Y_{t}=A K_{t}^{\alpha} L_{t}^{\beta}
$$

where aggregate output at time $t$ represents by $Y_{t}$, capital by $K_{t}$, labour by $L_{t}$, and technology parameter by $A$. Elasticities of output for capital and labour are represented by $\alpha$ and $\beta$ respectively. Current works on economic growth shows that capital, labor, technical development and energy are important components of economic growth in industrialized countries. Economic growth models, therefore, are dependent on five variables: production, capital, employment, energy and technical progress (Yuan et al. 2008). Based on previous studies by Rahman and Vilayutham (2019), Luqman and Al-Ansari (2020), Baz et al. (2021) and Liao et al. (2010), this study presents a cobb-douglas-production function which takes energy as an input together with other traditional inputs (labour and capital) in the following mathematical form:

$$
Y_{t}=A K_{t}^{\beta_{1}} L_{t}^{\beta_{2}} E C_{t}^{\beta_{3}}
$$

where energy represents by $E C_{t}$ and the elasticity of output with respect to energy represents by $\beta_{3}$. The conversion into a natural logarithm delivers effective empirical conclusions (Shahbaz et al., 2020; Ummalla and Raghutla, 2015). A more generic strategy is the log-linear transformation of the data set and all regression coefficients are interpreted as elasticity. The log-linear for the following equation results in the logarithmic form of the production function:

$$
\operatorname{Ln} Y_{t}=C_{0}+\beta_{1} \operatorname{Ln} K_{t}+\beta_{2} \operatorname{Ln} L_{t}+\beta_{3} \operatorname{LnEC} C_{t}+\varepsilon_{t}
$$


Where $L n$ is the natural $\log , C_{0}$ is the intercept, $\beta_{s}$ are the coefficients and $\varepsilon$ is the error term. Here, $\operatorname{Ln} Y_{t}, \operatorname{Ln} K_{t}, L n L_{t}$ and $L n E C_{t}$ represents $\log$ of real GDP, gross fixed capital formation $(K)$, labour $(L)$ and energy consumption $(E C)$.

\subsection{Data}

Yearly data has been utilized for 28 years which is from 1980 to 2018 for Malaysia in this study. It is noted that real $\operatorname{GDP}(Y)$ and gross fixed capital formation $(K)$ both are in constant 2010 US\$. The people who are 15 years old or older denotes a country's labor force. In many studies such as Soytas et al. (2007), Soytas and Sari (2009) and Shahbaz et al. (2017) have used labor force to proxy labor. Here, labor force is used in millions. Energy consumption indicates consumption of NRE and RE. NRE comprises of oil, natural gas, coal and RE includes solar, wind, biomass, hydro, geothermal and tidal wave. The NRE and RE units are measured in millions of tons of oil. Data are collected for the variables chosen from the World Development Indicators and the BP World Energy Statistical Review 2017 for the period 1980 to 2018. Data availability dictates the selection of the time period.

\subsection{Estimation Procedure}

The NARDL model employed in this work that capture asymmetric relation among the selected variables by improving previous linear autoregressive model (ARDL) which was developed by Pesaran et al. (2001). NARDL consists of a dynamic error correction model that permits shortterm and long-term asymmetries to be recorded. This methodological approach permits cointegration and asymmetric non-linearity concurrently in a single equation and performs better in smaller samples than previous techniques of co-integration (Ahmad, 2017; Romilly et al., 2001). In order to get exact and accurate findings, NARDL is more versatile in terms of the $\mathrm{I}(0), \mathrm{I}(1)$ or combination of $\mathrm{I}(0)$ and I(1) (Nusair, 2016). The methodology of Engle and Granger (Johansen, 1988) and the approach of Johansen (Johansen, 1991; Johansen, 1988) are conventional. The Johansen method limits the utilization of one of all variables, i.e. I(1) and Engle and Granger are used for causality purposes alone. The NARDL model has its features: the first is to estimate co-integration relationship among the selected variables using Ordinary Least Squares (OLS) to estimate the optimum number of lag. Secondly, given the order of integration $\mathrm{I}(0)$ or I(1)) or both, the NARDL approach remains relevant. Thirdly, it should be noted that NARDL is ideal for a small sample (Ahmad and Du, 2017). Fourthly, the NARDL test takes from the general to the specific framework a number of delays and records data production processes (Laurenceson and Chai, 2003). Because of these features, NARDL incorporates short-term equilibrium adjustments without loss of long-term information (Shin et al., 2014).

The NARDL model allows a variety of data series and integration orders, unlike earlier vector error correction model (VECM) in which the time series should have the same integration order (Hoang et al., 2016). For macroeconomic data, this flexibility is very significant. The shortterm and long-term NARDL (Shin et al., 2014) model was created utilising a positive and negative partial sum of non-linearity. A partial technique for integrating variables with increasing and declining asymmetric decomposition is required. The partial sum procedure can be used to define the increase in energy consumption $\left(E C^{+}\right)$and decrease in energy consumption $\left(E C^{-}\right)$and they can be written as follow:

$$
E C_{t}^{+}=\sum_{j=1}^{t} \Delta E C_{j}^{+}=\sum_{j=1}^{t} \max \left(\Delta E C_{j}, 0\right)
$$




$$
E C_{t}^{-}=\sum_{j=1}^{t} \Delta E C_{j}^{-}=\sum_{j=1}^{t} \min \left(\Delta E C_{j}, 0\right)
$$

The NARDL model which includes the asymmetric dynamics in short run and long run can be written as follows:

$$
\begin{aligned}
\Delta L n Y=\alpha_{0} & +\beta_{1} \ln Y_{t-1}+\beta_{2} \ln L_{t-1}+\beta_{3} \ln K_{t-1}+\beta_{4} \ln E C_{t-1}^{+}+\beta_{5} \ln E C_{t-1}^{-}+\sum_{i=1}^{q} \lambda_{i} \Delta Y_{t-i}+\sum_{i=0}^{q} \lambda_{i} \Delta L_{t-i} \\
& +\sum_{i=0}^{q} \lambda_{i} \Delta K_{t-i}+\sum_{i=0}^{q}\left(\lambda_{i}^{+} \Delta \ln E C_{t-i}^{+}+\lambda_{i}^{-} \Delta \ln E C_{t-i}^{-}\right)+u_{i}
\end{aligned}
$$

The null hypothesis $\left(H_{0}: \beta_{1}=\beta_{2}=\beta_{3}=\beta_{4}=\beta_{5}\right.$ ) denotes the bounds testing procedure by Pesaran et al. (2001). If we reject the null hypothesis, it will indicate that there is co-integrating relationship among the variables. Furthermore, long-run parameter are calculated as $\theta^{+}=\frac{\beta_{4}}{-\beta_{1}}$ and $\theta^{-}=\frac{\beta_{5}}{-\beta_{1}}$. If the hypothesis: $\theta^{+}=\theta^{-}$is rejected, it will confirm the asymmetric long run influence of renewable and non-renewable energy on economic growth. Similarly, if the hypothesis: $\lambda_{i}^{+}=\lambda_{i}^{-}$is rejected, it will demonstrate the asymmetric adjustment of the variables for the short run.

\subsection{Results and Discussion}

In this part, economic techniques are assessed for the relationship between NRE, RE and economic growth. Before conducting NARDL analysis, descriptive statistics and correlations were acquired. Table 1 demonstrates that the average consumption of NRE throughout the study period is significantly larger than that of RE consumption. In contrast with RE, however, NRE displays more instability. The correlation coefficients for all pairings of variables show positive correlation. The LnY series is closest to labour followed by NRE, K and RE.

Table 2 summarizes the results of the unit root tests. One of the main advantages of NARDL approaches is that this procedure is accurate regardless of whether all variables are integrated at the level or first difference or display the mixture results I (0) and I (1). The appropriate unit root tests must be applied to ensure none of the variables is integrated into order two I (2) (Pesaran et al., 2001; Demir, 2015; Haug \& Ucal, 2019; Udeagha \& Ngepah, 2020). Furthermore, if any variable displays integrated of order two, the estimated F-statistics produced by the Pesaran et al. (2001) bound testing procedure becomes invalid.

Moreover, the F-bound test yields two bound values: the upper bound value and the lower bound value; the assumption of stationary at level variables yields the lower bound values, i.e., I (0), and the assignment of the first difference stationary yields the upper bound values, i.e., I (1) (Ahmad et al., 2019; Belloumi, 2014; Udeagha \& Ngepah, 2020). Therefore, in this study, two standard time-series order of integration tests, Augmented Dickey-Fuller (ADF) and Phillips-Perron (PP), are used to verify that the study variables are not integrated into order two, I(2). Table 2 summarizes the results of both the ADF and PP tests to determine the order of integration for LnRE, LnNRE, LnL, Ln K and LnY in the case of Malaysia. Here, LnRE and LnNRE are logs of renewable energy and non-renewable energy consumption. Both tests with intercept and trend and intercept restrictions show that LnRE, LnNRE, LnL, Ln K and LnY are nonstationary at the level. In contrast, the estimation outputs of both tests with the same restrictions revealed that $\mathrm{LnNRE}$, LnRE, $\mathrm{LnL}$, $\mathrm{LnK}$ and $\mathrm{LnY}$ are stationary at the first difference. The unit root's null hypotheses are significantly rejected at a $5 \%$ level of 
significance after taking the first differences of the series. As a result, because the significance level of 5\% is chosen in this study to decide on the null hypothesis of unit root, both estimation output results of ADF and PP tests show that all variables are integrated into order one I (1). Therefore, the results confirm that none of the variables is integrated into order two, I (2); thus, the study can move forward with the asymmetric NARDL.

Table 3 demonstrates the BDS independence test of non-linearity. The BDS test introduced by Broock, et al., (1996), is a non-parametric test configured primarily to examine the same and independent distribution identical and independent distribution (IID). BDS test is a general test broadly used to check the model specification when used for residuals from fitted models (Kumar, 2017). The findings reveal that all the selected variables have a non-linear trend in all dimensions. The linearity (null hypothesis) is rejected at a $1 \%$ level of significance, while the alternative hypothesis is accepted, suggesting that the included variables are non-linear. Our outcomes show the accuracy and reliability of the estimated results and validate the model selection (Shahbaz, M et al., 2017). More specifically, it is worth mentioning that the specified model of economic growth is appropriate for policy making in Malaysia.

The Wald test results for assessing the equality of positive and negative shocks of NRE and $\mathrm{RE}$ are reported in Table 4. The results of Wald test support asymmetry, as it is significant for the long- run and short run. Initial literature has shown that both positive and negative shocks have disproportionate short-term and long-term impacts on their respective dependent variables. Table 4 shows overall results for expressing dynamic associations among variables in favour of the NARDL model. The lack of knowledge of asymmetries might lead to an improper modelling in any dynamic model. Table 4 also shows the analysis of diagnostic tests. The results of Breusch-Pagan- Godfrey heteroscedasticity test demonstrate that the null hypothesis of homoscedasticity cannot be rejected because the probability of chi-square value is insignificant. While, for serial correlation, the Breusch-Godfrey Serial Correlation LM test and for normality, Jarque-Bera test were conducted. The chi-square tests were shown to be statistically insignificant in both tests. These findings show there is no serial correlation among the independent variables and the data are normally distributed. The dynamic stability was checked with a cumulative resource residue amount (CUSUM) and a cumulative amount of recursive residual square (CUSUMQ) to further confirm the robustness of our results (Brown et al., 2003). Figures 4(A) and Figure 4(B) show that the recursive residuals of CUSUM and CUSUMSQ test statistics are within critical values at 5\% significant, suggesting that the series graphical plots are stable. The Durbin Watson test statistics (2.67) of the estimated model also confirms the nonexistence of autocorrelation. On the basis of Banerjee, et al. (1999), the tstatistic $\left(\mathrm{T}_{\mathrm{BDM}}\right)$ authenticates the cointegration among the selected variables at a $1 \%$ significance level. Likewise, according to Shin, Yu, and Greenwood-Nimmo (2001), the Fstatistics FPPS confirms asymmetric co-integration among LnNRE, LnRE, LnK, LnL and LnY. Table 5 summarizes the estimation results of NARDL.

The results shown in Table 5 reports that the NRE has a significant beneficial impact on economic growth in the long run, demonstrating that the use of energy plays a vital role in the nation's economy. The calculated elasticity of the positive shocks of NRE shows a rise of $1 \%$ in NRE consumption would increase economic growth by $0.580 \%$. In addition, the coefficient of negative shock of NRE indicates that a $1 \%$ decline in NRE would lead to a $0.042 \%$ fall in economic growth. Similar results have been found in the long run for Thailand (Araç \& Hasanov, 2014) and they indicate that other industrial factors may substitute energy on bad economic terms. Because energy is the power for all economic activity, a drop of 
NREconsumption will hinder economic activity and hence produce a weak, unforeseen economic growth. These debates should help policy makers to take the decision whether they will recommend the usage of RE which will replace in some extent the usage of NRE. The policy makers will also think of the detrimental impact of NRE on the environment. The government should be very discerning and vigilant in harnessing the use of energy effectively in several productive sectors through efficient ways. It may be eminent that the magnitude of the coefficient of the positive energy shocks on the economic growth is greater than that of negative energy shocks which demonstrates that an increase in NRE increases growth by a greater magnitude than a decrease in NRE augments the growth. It is to be noted that in the short run, the positive shocks in NRE has weaker but significant effect on the economic growth than in long run.

In the long run, a positive shock of RE seems to have a beneficial influence on economic growth (with a coefficient of 0.199). The positive sign of the coefficient shows that Malaysia will have a beneficial impact for renewable energy. The amount of the negative energy shocks' impact on economic growth is higher than that of positive energy shocks, which indicates that reduction in RE consumption increases economic growth in a bigger extent than the growth increases for increase in RE consumption. In short run, both the positive and negative shocks in the RE have similar relationship with economic growth as they have in the long run and the $t$-values indicate that their coefficients are significant. The negative shocks in RE have a greater and important influence on economic growth in the long-run than in the short-run. The findings are consistent with the studies conducted in Pakistan (Shahbaz et al. 2015) and in African nations (Apergis \& Payne, 2010).

The findings of the NARDL estimate can also demonstrate the comparative role of RE on economic growth in Malaysia. The results of NARDL show that the positive shocks of NRE are larger in the long and short- run than that of RE. It indicates that NRE is still playing the vital role for economic growth in Malaysia. Malaysia is 34\% better than other countries when it comes to energy use (ETP, 2013). Malaysia's average final energy demand growth rate is expected to be 5.2 percent year (1990 to 2013). Malaysia is dependent more on NRE because this country is diversified from agricultural to energy-intensive production activities during the research period. The production activities in Malaysia are characterized by the usage of high energy and generally high energy intensity generation processes. Energy intensity is an indicator that shows how efficiently the energy is used in the economy. The energy intensity of Malaysia is higher than that of many established and emerging economies (Global Energy Statistical Yearbook, 2019). Any efforts taken to save energy should thus have in mind the substantial economic development impacts of NRE. Malaysia has to develop solutions to enhance the quality and quantity of services while mitigating the consequences of energy usage on the environment (IEA, 2005). In the long term, RE's negative shocks, on the other hand, are larger than NRE's. This finding shows that the use of RE cannot have a beneficial effect on the Malaysian economy. In its production process Malaysia is still unwilling to replace NRE and employ it. Finally, the other two factors, labour and capital, have a significant benefit for both short-term and long-term economic growth. Government and policy makers in growing nations such as Malaysia must supervise capital investment. Capital investment is required for economic growth. The empirical data contribute to the presence of an asymmetric connection among RE, NRE and economic growth in Malaysia. Figure 5(A) confirms the presence of positive shocks in NRE dominated by negative shocks. In contrast, negative shocks in RE dominates positive shocks (Figure 5(B)), which means a negative association between RE and economic growth. 


\subsection{Conclusions and Actions Recommendations}

$\mathrm{RE}$ is a clean form of energy that causes less environmental damage and is of greater relevance in RE development for the majority of the country. In addition, using RE reduces NRE dependence. This study investigates the links between RE, NRE, capital, labour and economic growth, using the NARDL method in Malaysia for the period of 1980-2018. The results of NARDL show that the positive shocks of NRE are larger in the long and short term than that of RE. It indicates that NRE is still playing the vital role for economic growth in Malaysia. The empirical conclusions of this study showed that reductions in RE consumption speed up economic growth. It can have argued that economic growth might be adversely affected in a developing nation by the usage of RE since RE is costlier than NRE. Moreover, an ongoing rise in the supply of renewable energy will impact the cost of production for most renewable sources. Shafie et al. (2011) forecast that Malaysia faced a growing RE fund scarcity and, by optimizing Feed in Tariff (FiT) payments across different periods, the government will raise its income by increasing electricity rates or cutting its expenditures in order to meet the budget deficit. The governments should thus foster RE sources and enable investors to acquire licenses, enterprises, grids and land. In this respect, Malaysia might focus on the installation of the latest technologies for saving energy. In the case of NRE, however, NRE has short-term positive shocks. A variety of measures to develop RE are recommended based on the results of the study. The following are:

a) It is recommended that development of RE requires an adequate, strong and efficient regulatory framework, which would solve market failures and encourage companies to enter the RE generating sector. In the legislative framework, FiT should be introduced, a stimulus for the entry into the RE-energy sector, RE industries and research and development (R\&D). In addition, RE fund can be developed to reduce the environmental pollution and society can play a role in contributing to a fund to pay through electricity bills. This is particularly relevant because retail tariffs contain subsidies and are being decreased and the external expenses are excluded. A technique might be used by including a specified cost into a particular RE fund inside the energy price structure. Consequently, a regulator that would function as a catalyst in the development of RE industries, $\mathrm{R} \& \mathrm{D}$ in RE technology and innovation has a direct spillover impact. These results include the pace of increase in the usage of RE, progressive (or constant) decrease in the consumption of fossil fuels for the conventional generation of electricity and the reduction of $\mathrm{CO}_{2}$ emissions.

b) It is suggested that incentive package that includes fiscal stimuli and indirect support should be implemented for the reduction of transaction costs and support to small medium enterprises (SMEs) in the RE sector. RE is a novel technology in Malaysia, which requires human resource development in support of RE industry development. A comprehensive R\&D plan, which leads to new items and services, must thus be established to accelerate the growth in RE industries. Innovation also helps the spread of RE by making the use of the technology cheaper and easier. Therefore, an R\&D strategy to define demand has to be developed, regulations are used to stimulate innovation and R\&E activities must be supported.

c) Advocacy programmes should be tailored to specific messages for certain populations. For example, an investment advocacy campaign and a RE market entry must communicate a message significantly different from a common public advocacy programme, aimed to achieve a buy-in to the notion of clean social payments. The common objective of all advocacy programmes is to raise knowledge of the benefits and benefits of utilizing RE and involvement in RE 
companies by all stakeholders. Once the foundation has been established, the policy mission should be evaluated and (if required) enhanced for time. For example, if the policy is revised in five years' time, a suitable regulatory structure would have fulfilled to incorporate the regulation. Nevertheless, as part of the continuous policy vision mission, it might need to be further enhanced or replaced as needed by a fresh impetus.

d) Human capital development is a crucial driving force, because it may be the country's biggest influence. The government of Malaysia acknowledges the importance of human development, as it may increase Malaysian economy's entire productivity and flexibility, which is essential for the transition between the community and the economy, and urges the government to provide the necessary infrastructure. However, given that the proportions of people with university education in the country are modest (about 13.9 percent in 2001) it is essential to encourage people to join tertiary colleges. This entails determining what motivates a person to receive a high school education and how the government might encourage these people. So, RE experts should be generated simultaneously to promote the development of new skills and capacities for regular people. However, such procedures are subject to a sunset condition. institutional preparations to achieve this goal need to be coordinated by the Ministry of Finance, Higher Education, Human Resources Minister and other governmental bodies concerned. 


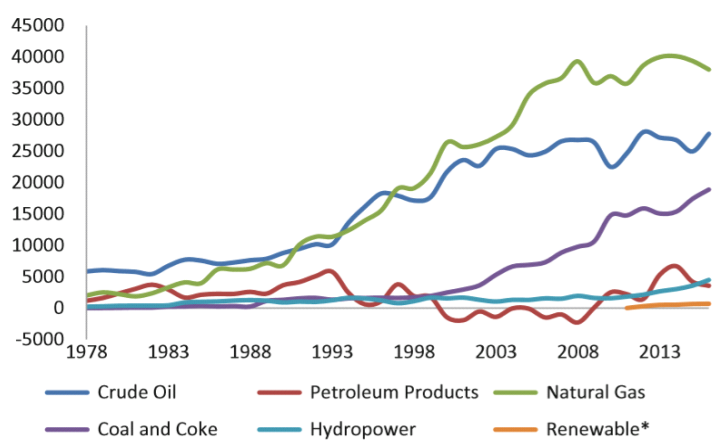

Figure 1: Malaysian energy mix production from 1978 until 2015 (Energy Commission Malaysia, 2019)

(A)

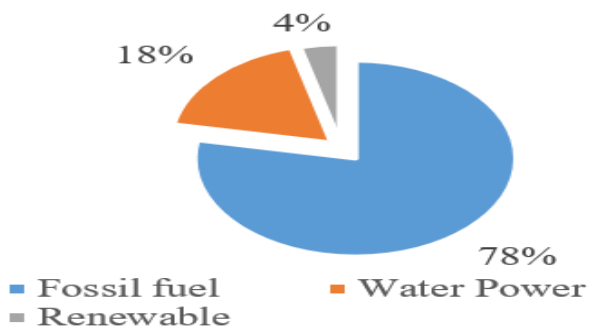

(B)

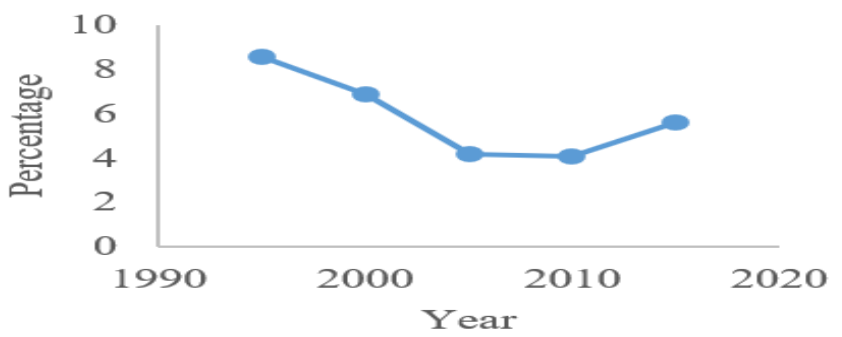

(C)

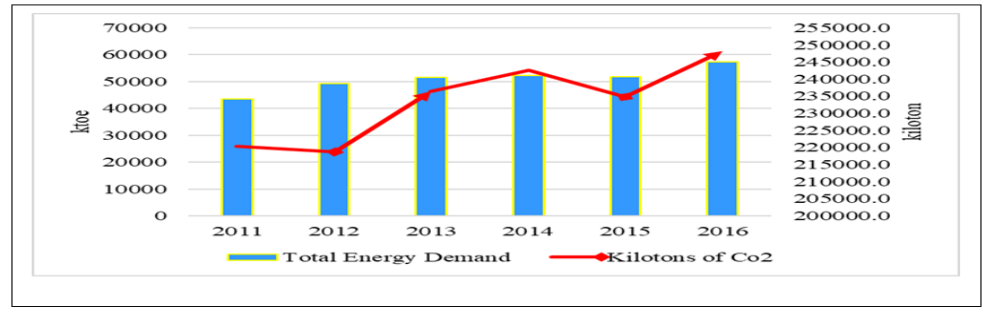

Figure 2. The production capacity of per energy source in terms of millions of tons of oil is shown in (A), Usage of renewable energy in \% term is shown in (B), and $\mathrm{CO}_{2}$ emission (kt) and total energy demand in Malaysia during 2008 to 2018 is shown in (C).

Source: Authors' own calculations using MS excel based on data retrieved from https://www.worlddata.info/asia/pakistan/energy consumption.php 


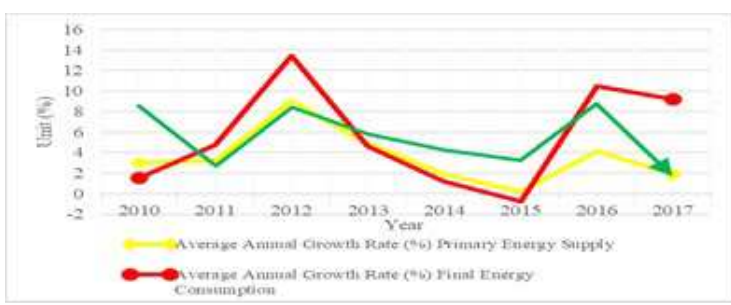

Figure 3: Average Annual Growth Rate of energy supply and consumption of Malaysia from 2010 to 2017

Source: Energy Commission Malaysia, 2019

(A)

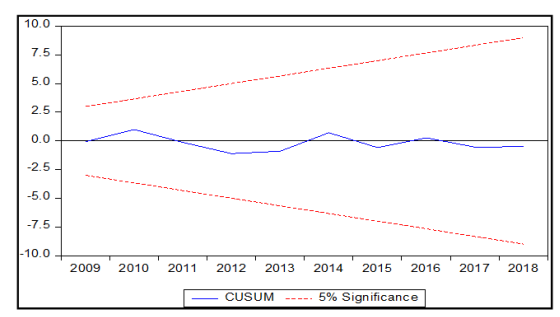

(B)

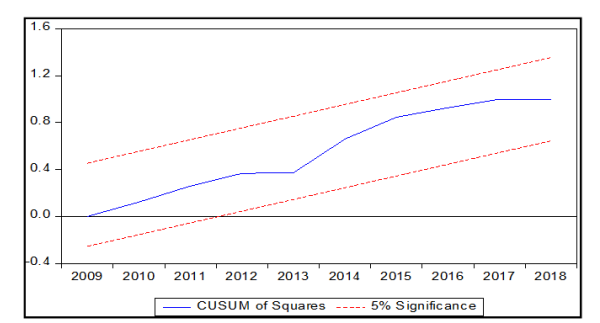

Figure 4. cumulative sum of recursive residuals (CUSUM) is shown in (A), and cumulative sum of recursive residual square (CUSUMQ) is shown in (B),
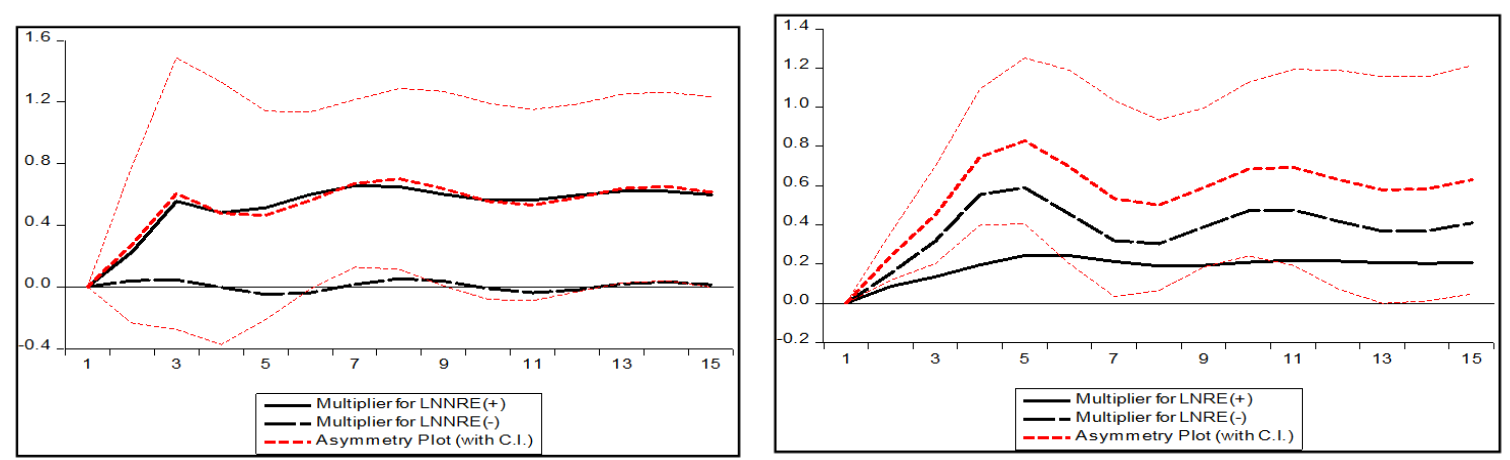

Figure 5. Cumulative effect of non-renewable energy on economic growth is shown in (A), and Cumulative effect of renewable energy on economic growth is shown in (B) 
Table 1: Descriptive Statistics

\begin{tabular}{lccccc}
\hline & LNY & LNK & LNL & LNNRE & LNRE \\
\hline Mean & 2.506 & 10.563 & 7.137 & 5.100 & 4.005 \\
\hline Median & 2.540 & 10.628 & 7.149 & 5.135 & 3.984 \\
\hline Maximum & 2.940 & 10.973 & 7.340 & 5.485 & 4.635 \\
\hline Minimum & 2.019 & 10.061 & 6.895 & 4.534 & 3.382 \\
\hline Std. Dev. & 0.282 & 0.280 & 0.140 & 0.296 & 0.286 \\
\hline Skewness & -0.221 & -0.408 & -0.184 & -0.437 & 0.042 \\
\hline Kurtosis & 1.782 & 1.987 & 1.737 & 1.886 & 3.560 \\
\hline Jarque-Bera & 2.728 & 2.751 & 2.811 & 3.257 & 0.521 \\
\hline Probability & 0.256 & 0.253 & 0.245 & 0.196 & 0.771 \\
\hline Sum & 97.736 & 411.966 & 278.361 & 198.912 & 156.185 \\
\hline Sum Sq. Dev. & 3.028 & 2.981 & 0.742 & 3.335 & 3.112 \\
\hline Pairwise Correlation & 1 & & & \\
\hline LNGDP & 1 & \multicolumn{7}{c}{} & \\
\hline LNK & 0.959178 & 1 & & & \\
\hline LNL & 0.996202 & 0.933899 & 1 & \\
\hline LNNRE & 0.990738 & 0.937108 & 0.991521 & 1 & \\
\hline LNRE & 0.844648 & 0.798316 & 0.845221 & 0.831464 & 1 \\
\hline
\end{tabular}

Table 2. Unit Root Test

\begin{tabular}{|c|c|c|c|c|c|c|c|c|}
\hline \multirow{3}{*}{ variables } & \multicolumn{4}{|c|}{ Augmented Dickey-Fuller (ADF) } & \multicolumn{4}{|c|}{ Phillips-Perron (PP) } \\
\hline & \multicolumn{2}{|c|}{$\begin{array}{c}\text { Stationarity at } \\
\text { level }\end{array}$} & \multicolumn{2}{|c|}{$\begin{array}{l}\text { Stationarity } 1^{\text {st }} \\
\text { difference }\end{array}$} & \multicolumn{2}{|c|}{$\begin{array}{c}\text { Stationarity at } \\
\text { level }\end{array}$} & \multicolumn{2}{|c|}{$\begin{array}{c}\text { Stationarity } 1 \mathrm{st} \\
\text { difference }\end{array}$} \\
\hline & Intercept & $\begin{array}{l}\text { Trend } \\
\text { and } \\
\text { intercept }\end{array}$ & Intercept & $\begin{array}{l}\text { Trend and } \\
\text { intercept }\end{array}$ & Intercept & $\begin{array}{l}\text { Trend and } \\
\text { intercept }\end{array}$ & Intercept & $\begin{array}{l}\text { Trend } \\
\text { and } \\
\text { intercept }\end{array}$ \\
\hline LnRE & -2.39 & 0.11 & $-3.91^{* *}$ & $-3.17^{* *}$ & -2.26 & 0.96 & $-3.12^{* *}$ & $-3.78^{* *}$ \\
\hline LnNRE & -2.64 & -2.08 & $-5.09^{* *}$ & $-5.91^{* *}$ & -1.24 & -1.77 & $-5.03^{* *}$ & $-6.10^{* *}$ \\
\hline $\mathrm{LnL}$ & -0.62 & -1.89 & $-5.49^{* *}$ & $-5.16^{* *}$ & 0.22 & -1.19 & $-3.32^{* *}$ & $-3.24^{* *}$ \\
\hline LnK & -1.54 & -2.22 & $-4.21^{* *}$ & $-3.51^{* *}$ & -1.54 & -2.22 & $-4.18^{* *}$ & $-4.05^{* *}$ \\
\hline LnY & -1.07 & -1.94 & $-4.14^{* *}$ & $-4.08^{* *}$ & -1.07 & -1.94 & $-4.08^{* *}$ & -4.02 \\
\hline
\end{tabular}

$(*)$ and $(* *)$ represent $1 \%$ and $5 \%$ level of significance, respectively.

Table 3. Non-linearity test.

\begin{tabular}{lccccc}
\hline Variables & $\mathrm{m}=2$ & $\mathrm{~m}=3$ & $\mathrm{~m}=4$ & $\mathrm{~m}=5$ & $\mathrm{~m}=6$ \\
\hline LnNRE & 0.1432 & 0.2197 & 0.2667 & 0.3063 & 0.3443 \\
\hline LnRE & 0.2037 & 0.3439 & 0.4456 & 0.5734 & 0.5646 \\
\hline LnL & 0.2056 & 0.3739 & 0.4476 & 0.3791 & 0.5728 \\
\hline LnK & 0.1787 & 0.2947 & 0.3742 & 0.4296 & 0.4691 \\
\hline LnGDP & 0.2037 & 0.3443 & 0.4428 & 0.5230 & 0.5663 \\
\hline
\end{tabular}


Table 4. Wald test and Diagnostic test.

\begin{tabular}{|c|c|c|c|c|}
\hline \multirow[t]{2}{*}{ Variables } & \multicolumn{2}{|c|}{ Wald test statistics } & \multicolumn{2}{|c|}{ Diagnostic Test } \\
\hline & Long run & Short run & Tests & Results \\
\hline LnNRE & $-2.76 * *$ & $5.13^{* *}$ & Heteroscedasticity & $6.32(0.123)$ \\
\hline LnRE & $-2.28^{* *}$ & $4.86^{* *}$ & Serial Correlation & $8.43(0.467)$ \\
\hline FPPS & $12.42^{*}$ & & Darbin Watson & 2.67 \\
\hline $\mathrm{T}_{\mathrm{BDM}}$ & $-4.32^{*}$ & & Adjusted $\mathrm{R}^{2}$ & 0.689 \\
\hline
\end{tabular}

$(*)$ and $(* *)$ represent $1 \%$ and $5 \%$ level of significance, respectively.

Table 5. Estimation results of NARDL

\begin{tabular}{ccccc}
\hline Variable & Coefficient & Std. Error & t-Statistic & Prob. \\
\hline & Panel A: Long-run estimates & \\
\hline LNK & 0.333 & 0.042 & 7.886 & $0.000^{*}$ \\
\hline LNL & -2.338 & 0.893 & -2.618 & $0.026^{* *}$ \\
\hline LNNRE_POS & 0.580 & 0.136 & 4.264 & $0.002^{* *}$ \\
\hline LNNRE_NEG & 0.042 & 0.323 & 0.131 & 0.898 \\
\hline LNRE_POS & 0.199 & 0.063 & 3.173 & $0.010^{* *}$ \\
\hline LNRE_NEG & -0.392 & 0.102 & -3.821 & $0.003^{*}$ \\
\hline \multicolumn{5}{c}{ Panel A: Short-run estimates } \\
\hline D(LNGDP(-1)) & 0.727 & 0.178 & 4.080 & $0.002^{* *}$ \\
\hline D(LNK) & 0.267 & 0.025 & 10.777 & $0.000^{* *}$ \\
\hline D(LNL) & 2.997 & 2.402 & 1.248 & 0.241 \\
\hline D(LNNRE_POS) & 0.226 & 0.065 & 3.483 & $0.006^{* *}$ \\
\hline D(LNRE_POS) & 0.085 & 0.035 & 2.436 & $0.035^{* *}$ \\
\hline D(LNRE_NEG) & -0.154 & 0.042 & -3.696 & $0.004^{* *}$ \\
\hline
\end{tabular}

$(*)$ and $(* *)$ represent $1 \%$ and $5 \%$ level of significance, respectively 


\section{Reference:}

Ahmad M, Ul Haq Z, Khan Z, Khattak SI, Ur Rahman Z, Khan S (2019) Does the inflow of remittances cause environmental degradation? Empirical evidence from China. Economic research-Ekonomska istraživanja 32(1):2099-2121. https://doi.org/10.1080/1331677X.2019.1642783

Ahmad N, Du L (2017) Effects of energy production and $\mathrm{CO}_{2}$ emissions on economic growth in Iran: ARDL approach. Energy 123(March):521-537. https://doi.org/10.1016/j.energy.2017.01.144

Ahmad N, Du L, Lu J, Wang J, Li HZ, Hashmi MZ (2017) Modelling the $\mathrm{CO}_{2}$ emissions and economic growth in Croatia: is there any environmental Kuznets curve?. Energy 123(March):164-172. https://doi.org/10.1016/j.energy.2016.12.106

Ahmad S, Ab Kadir MZ, Shafie S (2011) Current perspective of the renewable energy development in Malaysia. Renewable and sustainable energy reviews 15(2):897-904. https://doi.org/10.1016/j.rser.2010.11.009

Apergis N, Payne JE (2010) Coal consumption and economic growth: Evidence from a panel of OECD countries. Energy Policy. 38(3):1353-1359. https://doi.org/10.1016/j.enpol.2009.11.016

Araç A, Hasanov M (2014) Asymmetries in the dynamic interrelationship between energy consumption and economic growth: Evidence from Turkey. Energy Economics (July):259-69. https://doi.org/10.1016/j.eneco.2014.04.013

Ashnani MH, Johari A, Hashim H, Hasani E (2014) A source of renewable energy in Malaysia, why biodiesel?. Renewable and Sustainable Energy Reviews 35(July):244-57. https://doi.org/10.1016/j.rser.2014.04.001

Baz K, Cheng J, Xu D, Abbas K, Ali I, Ali H, Fang C (2021) Asymmetric impact of fossil fuel and renewable energy consumption on economic growth: A nonlinear technique. Energy 226(July):120357. https://doi.org/10.1016/j.energy.2021.120357

Baz K, Xu D, Ampofo GM, Ali I, Khan I, Cheng J, Ali H (2019) Energy consumption and economic growth nexus: New evidence from Pakistan using asymmetric analysis. Energy. 189(Dec):116254. https://doi.org/10.1016/j.energy.2019.116254

Begum RA, Sohag K, Abdullah SM, Jaafar M (2015) $\mathrm{CO}_{2}$ emissions, energy consumption, economic and population growth in Malaysia. Renewable and Sustainable Energy Reviews 41(Jan):594-601. https://doi.org/10.1016/j.rser.2014.07.205

Belloumi M (2014) The relationship between trade, FDI and economic growth in Tunisia: An application of the autoregressive distributed lag model. Economic systems 38(2):269-287. https://doi.org/10.1016/j.ecosys.2013.09.002

Brock W, Dechert W, Scheinkman J, LeBaron B (2001) Growth theory, non-linear dynamics, and economic modelling: scientific essays of William Allen Brock. UK: Edward Elgar Publishing.

Central Intelligence Agency (2011) The World Factbook. Accessed from: https://www.cia.gov/library/publications/the-world-factbook/geos/my.html (Accessed on: September 28, 2020)

Chen C, Pinar M, Stengos T (2020) Renewable energy consumption and economic growth nexus: Evidence from a threshold model. Energy Policy 139(April):111295. https://doi.org/10.1016/j.enpol.2020.111295

COP15 (2009) United Nations Climate Change conference on climate change global risk challenges \& decisions. Available at: https://www.certh.gr/dat/22FB0268/file.pdf

Dolado JJ, Lütkepohl H (1996) Making Wald tests work for cointegrated VAR systems. Econometric reviews 15(4):369-386. https://doi.org/10.1080/07474939608800362 
Energy Commission (ST) Malaysia (2017) Energy in Malaysia: Towards a brighter future. Vol. 12. Selangor, Malaysia: The IBR Asia Group.

Energy Commission (ST) Malaysia (2019) Malaysia energy statistics handbook 2019. Putrajaya, Malaysia: Energy Commission. Available at: https://meih.st.gov.my/documents/10620/bcce78a2-5d54-49ae-b0dc-549dcacf93ae (Accessed on: 15 July 2020).

Ghali KH, El-Sakka MI (2004) Energy use and output growth in Canada: a multivariate cointegration analysis. Energy economics 26(2):225-238. https://doi.org/10.1016/S01409883(03)00056-2

Global Energy Statistical Yearbook (2019) Total energy consumption. Global Energy Statistical Yearbook.

Haug AA, Ucal M (2019) The role of trade and FDI for $\mathrm{CO}_{2}$ emissions in Turkey: Nonlinear relationships. Energy Economics 81(June):297-307. https://doi.org/10.1016/j.eneco.2019.04.006

Hoang LP, Lauri H, Kummu M, Koponen J, Van Vliet MT, Supit I, Leemans R, Kabat P, Ludwig F (2016) Mekong River flow and hydrological extremes under climate change. Hydrology and Earth System Sciences 20(7):3027-3041. https://doi.org/10.5194/hess-20$\underline{3027-2016}$

IEA (2005) $\mathrm{CO}_{2}$ emissions from fuel combustion 1971-2003. Paris: International Energy Agency (IEA).

Ike GN, Usman O, Alola AA, Sarkodie SA (2020) Environmental quality effects of income, energy prices and trade: the role of renewable energy consumption in G-7 countries. Science of The Total Environment 721(June):137813. https://doi.org/10.1016/j.scitotenv.2020.137813

Inglesi-Lotz R, Dogan E (2018) The role of renewable versus non-renewable energy to the level of $\mathrm{CO} 2$ emissions a panel analysis of sub-Saharan Africa's Big 10 electricity generators. Renewable Energy 123(August):36-43. https://doi.org/10.1016/j.renene.2018.02.041

Isik C, Dogru T, Turk ES (2018) A nexus of linear and non-linear relationships between tourism demand, renewable energy consumption, and economic growth: Theory and evidence. International Journal of Tourism Research 20(1):38-49. https://doi.org/10.1002/jtr.2151

Javid M, Sharif F. Environmental Kuznets curve and financial development in Pakistan. Renewable and Sustainable Energy Reviews. 54:406-414. https://doi.org/10.1016/j.rser.2015.10.019

Johansen S (1988) Statistical analysis of cointegration vectors. Journal of economic dynamics and control 12(2-3):231-54. https://doi.org/10.1016/0165-1889(88)90041-3

Johansen S (1991) Estimation and hypothesis testing of cointegration vectors in Gaussian vector autoregressive models. Econometrica: Journal of the Econometric Society 1(Nov):1551-1580. https://doi.org/10.2307/2938278

Kumar S (2017) On the nonlinear relation between crude oil and gold. Resources Policy 51(March):219-24. https://doi.org/10.1016/j.resourpol.2017.01.003

Laurenceson, J., \& Chai, J. C. (2003). Financial reform and economic development in China. Edward Elgar Publishing.

Li Z, Solaymani S (2021) Effectiveness of energy efficiency improvements in the context of energy subsidy policies. Clean Technologies and Environmental Policy 23(3):937-963. https://doi.org/10.1007/s10098-020-02005-8

Liao Q, Wu Z, Xu J (2010) A new production function with technological innovation factor and its application to the analysis of energy-saving effect in LSD. Modelling and Simulation 6(4):257-266. 
Li, Y., \& Solaymani, S. (2021). Energy consumption, technology innovation and economic growth nexuses in Malaysian. Energy, 121040.

Luqman, M., Ahmad, N., \& Bakhsh, K. (2019). Nuclear energy, renewable energy and economic growth in Pakistan: Evidence from non-linear autoregressive distributed lag model. Renewable Energy, 139, 1299-1309.

Maji IK, Sulaiman C, Abdul-Rahim AS (2019) Renewable energy consumption and economic growth nexus: A fresh evidence from West Africa. Energy Reports 5(Nov):384-392. https://doi.org/10.1016/j.egyr.2019.03.005.

Nurgazina, Z., Ullah, A., Ali, U., Koondhar, M. A., \& Lu, Q. (2021). The impact of economic growth, energy consumption, trade openness, and financial development on carbon emissions: empirical evidence from Malaysia. Environmental Science and Pollution Research, 1-14.

Nugraha AT, Osman NH (2019) $\mathrm{CO}_{2}$ emissions, economic growth, energy consumption, and household expenditure for Indonesia: Evidence from cointegration and vector error correction model. International Journal of Energy Economics and Policy 9(1):291-298. http://doi.org/10.32479/ijeep.7295

Nusair SA (2016) The effects of oil price shocks on the economies of the Gulf Co-operation Council countries: Nonlinear analysis. Energy Policy 91(April):256-267. https://doi.org/10.1016/j.enpol.2016.01.013

Omri A (2014) An international literature survey on energy-economic growth nexus: Evidence from country-specific studies. Renewable and Sustainable Energy Reviews 38(Oct):951959. https://doi.org/10.1016/j.rser.2014.07.084

Pesaran MH, Shin Y, Smith RJ (2001) Bounds testing approaches to the analysis of level relationships. Journal of applied econometrics 16(3):289-326. https://doi.org/10.1002/jae.616

Poh KM, Kong HW (2002) Renewable energy in Malaysia: a policy analysis. Energy for Sustainable Development 6(3):31-39. https://doi.org/10.1016/S0973-0826(08)60323-3

Rahman MM, Velayutham E (2020) Renewable and non-renewable energy consumptioneconomic growth nexus: new evidence from South Asia. Renewable Energy 147(March):399-408. https://doi.org/10.1016/j.renene.2019.09.007

Romilly P, Song H, Liu X (2001) Car ownership and use in Britain: a comparison of the empirical results of alternative cointegration estimation methods and forecasts. Applied economics 33(14):1803-1818. https://doi.org/10.1080/00036840011021708 .

Shastri, S., Mohapatra, G., \& Giri, A. K. (2020). Economic growth, renewable and nonrenewable energy consumption nexus in India: Evidences from nonlinear ARDL approach and asymmetric causality analysis. International Journal of Energy Sector Management.

Saudi MH, Sinaga O, Roespinoedji D, Razimi MS (2019) The role of renewable, nonrenewable electricity consumption and carbon emission in development in Indonesia: Evidence from Distributed Lag Tests. International Journal of Energy Economics and Policy 9(3):46-52. https://doi.org/10.32479/ijeep.7730

Shaari MS, Rahim HA, Rashid IM (2013) Relationship among population, energy consumption and economic growth in Malaysia. International Journal of Social Science 13(1):40-45.

Shafie SM, Mahlia TM, Masjuki HH, Andriyana A (2011) Current energy usage and sustainable energy in Malaysia: A review. Renewable and Sustainable Energy Reviews 15(9):4370-4377. https://doi.org/10.1016/j.rser.2010.11.009 
Shah SZ, Chughtai S, Simonetti B (2020) Renewable energy, institutional stability, environment and economic growth nexus of D-8 countries. Energy Strategy Reviews 29(May):100484. https://doi.org/10.1016/j.esr.2020.100484

Shahbaz M, Loganathan N, Zeshan M, Zaman K (2015) Does renewable energy consumption add in economic growth? An application of auto-regressive distributed lag model in Pakistan. Renewable and Sustainable Energy Reviews 44(April):576-585. https://doi.org/10.1016/j.rser.2015.01.017

Shahbaz M, Raghutla C, Chittedi KR, Jiao Z, Vo XV (2020) The effect of renewable energy consumption on economic growth: Evidence from the renewable energy country attractive index. Energy 207(Sep):118162. https://doi.org/10.1016/j.energy.2020.118162

Shahbaz M, Van Hoang TH, Mahalik MK, Roubaud D (2017) Energy consumption, financial development and economic growth in India: New evidence from a nonlinear and asymmetric analysis. Energy Economics 63(March):199-212. https://doi.org/10.1016/j.eneco.2017.01.023

Shahbaz M, Van Hoang TH, Mahalik MK, Roubaud D (2017) Energy consumption, financial development and economic growth in India: New evidence from a nonlinear and asymmetric analysis. Energy Economics 63(March):199-212. https://doi.org/10.1016/j.eneco.2017.01.023

Shin Y, Yu B, Greenwood-Nimmo M (2014) Modelling asymmetric cointegration and dynamic multipliers in a nonlinear ARDL framework. InFestschrift in honor of Peter Schmidt (pp. 281-314). Springer, New York, NY. https://doi.org/10.1007/978-1-4899-8008-3_9

Shin, Y., Yu, B., \& Greenwood-Nimmo, M. (2014). Modelling asymmetric cointegration and dynamic multipliers in a nonlinear ARDL framework. In Festschrift in honor of Peter Schmidt (pp. 281-314). Springer, New York, NY.

Solow RM (1956) A contribution to the theory of economic growth. The quarterly journal of economics 70(1):65-94. https://doi.org/10.2307/1884513

Soytas U, Sari R (2009) Energy consumption, economic growth, and carbon emissions: challenges faced by an EU candidate member. Ecological economics 68(6):1667-1675. https://doi.org/10.1016/j.ecolecon.2007.06.014

Soytas U, Sari R, Ewing BT (2007) Energy consumption, income, and carbon emissions in the United States. Ecological Economics 62(3-4):482-489. https://doi.org/10.1016/j.ecolecon.2006.07.009

Štreimikienė D, Baležentis A (2015) Assessment of willingness to pay for renewables in Lithuanian households. Clean Technologies and Environmental Policy 17(2):515-531. https://doi.org/10.1007/s10098-014-0810-Z

Tang CF, Tan BW (2014) The linkages among energy consumption, economic growth, relative price, foreign direct investment, and financial development in Malaysia. Quality \& Quantity 48(2):781-897. https://doi.org/10.1007/s11135-012-9802-4

Toda HY, Yamamoto T (1995) Statistical inference in vector autoregressions with possibly integrated processes. Journal of econometrics 66(1-2):225-250. https://doi.org/10.1016/0304-4076(94)01616-8

Udeagha MC, Ngepah N (2021) The asymmetric effect of trade openness on economic growth in South Africa: a nonlinear ARDL approach. Economic Change and Restructuring 54(2):491-540. https://doi.org/10.1007/s10644-020-09285-6

Ummalla M, Raghutla C (2015) Exports, imports and economic growth in India: An empirical analysis. The Empirical Economics Letters 14(7):689-696. https://ssrn.com/abstract $=3150164$

World Bank (2020) GDP per capita (current US\$) - Malaysia. Retrieved from: https://data.worldbank.org/indicator/NY.GDP.PCAP.CD?locations=MY (Accessed on: 29 July 2020). 
World Energy Markets Observatory (WEMO) report (2017) World energy markets observatory: A strategic overview of the global energy markets, $19^{\text {th }}$ Ed. Capgemini. Available at: https://www.capgemini.com/wp-content/uploads/2017/11/wemo2017vst27-web.pdf 